\begin{tabular}{ccc}
\hline International Journal of Engineering \& Technology, $7(4.38)(2018) 1345-1349$ \\
SPC \\
Website: www.sciencepubco.com/index.php/IJET \\
Research paper
\end{tabular}

\title{
Proposing Islamic Values Implementation in Workplace:Analysis via Rasch Model
}

\author{
Amal Hayati Ishak*, Siti Khadijah Ab Manan, Rafeah Saidon, Noorul Huda Sahari
}

Academy of Contemporary Islamic Studies, Universiti Teknologi MARA, Shah Alam 40450 Selangor, Malaysia

\begin{abstract}
Previous and current research has long been indulged into empirical study of values. Nevertheless, these research are limitedly focused on the influence of values to performance or other variables, and undoubtedly agree on the significant function of values in workplace. However, guiding principles for organisations to apply the values in working environment has been marginally suggested or provided, as a by-product of scientific research. Thus this article proposes two sets of values application in workplace; the basic and advanced practices of values. The first refers to introductory values which should be introduced to organisational members prior to the letter. The sets of values are resulted from Rasch Model analysis of item difficulty and person ability.
\end{abstract}

Keywords: Islamic values, Item difficulty, Rasch Model, Person ability

\section{Introduction}

The significance of values in organisations has been proven in history. The Japanese were reported to have significant economic success post World War II owing to their innate good values (Ishikawa, 1985; Khaliq \& Shamim, 1996; Naceur, 2005). In parallel, research on the significance of values in workplace are conducted to scientifically approve on its influence (Maull, Brown \& Cliffe, 2001; Prajogo \& McDermott, 2005; 2011; Zu, Robbins \& Fredendall, 2010; Baird, Hu \& Reeve, 2011; Gambi, Gerolamo \& Carpinetti, 2013). However, these studies are grounded on general framework of Hofstede's cultural dimensions (Baird et al., 2011), Competing Value Framework of O'Reilly (Al-Khalifa \& Aspinwall, 2001) and Organisational Culture Profile of Quinn and Rohrbaugh (Denison \& Spritzer, 1991). These studies revealed different sets of values significant to be applied in workplace for the betterment of organisations. For instance, teamwork is found significant by Baird et al. (2011), Zu et al. (2010) and Lagrosen (2003), while development is found significant according to Prajogo and McDermott (2005). However, these research has not been referred to any Islamic substance.

Nevertheless, contemporary studies have conceptualised the relation of Islamic values to organisational effectiveness (Ishak \& Osman, 2015; Ishak, Osman, \& Din, 2013). Contemporary scholars, such as Khaliq (1996); Khaliq and Abulhasan (1996); alBuraey (2005); Siti Arni et al. (2010); Sany Sanuri et al. (2011); Ilhaamie et al. (2013); Arbain et al. (2014); Ishak and Osman (2015); and Ishak and Osman (2016) have been highlighting the conceptual elaboration on a list of values, underpinned with Islamic substance.

Apart from that, there are a number of research focusing on developing valid and reliable tools to measure Islamic values. The tools are applied in various contexts including behaviour and religiosity. Among them are the works of Abbas (1987), Abdul Lateef, Azimi, Rumaya and Jamaliah (2005), Asma and Priester (2007), Latif (2013) and Ishak (2016). Unanimously, these studies stress on the importance of Islamic values but do not recommend the ranking order of values application. Thus this article proposes a ranking order which can be translated into basic values and advanced values. The basic values may provide insights on values which need to be introduced to organisational members prior to the set of advanced values.

\section{Conceptualising Islamic Values}

Islam has been revealed to Prophet Muhammad SAW since his prophethood in $609 \mathrm{CE}$ until $632 \mathrm{CE}$. Its revelation has successfully reform the conditions of the pagan Arabs from corruption and harmful customs (Hitti, 1960). Islam offers a systematic regulated way of life which caters the interest of the whole society. For instance, Islam calls for safeguarding benefits and avoid detriments. Islam prohibited interest due to its tyranny towards the poor and needy; fornication due to its exploitation of women and damage of family ties; alcohol due to physical and emotional damage individually and collectively. Despite certain prohibitions, as a replacement to the prohibitions, Islam obligated and suggested modes of just and transparent business dealings, marriage for a proper relationship between man and women and a wide range of permissible foods which are wholesome and beneficial to be taken by man. These

unexhausted list of life guidance has reformed human conditions encompassing all facets (Phillips, 1995).

Islam also emphasizes good conducts, and Prophet Muhammad was sent as the Messenger, also as an exemplar for man. Since the demise of The Prophet, the Muslims are left with two authentic sources which are relevant irrespective of time, space and locality. The two sources refer to the Quran, defined as the book of words of God; and the Sunnah, or Prophetic traditions, defined as sayings, actions and tacit approval of Prophet Muhammad.

Islamic values refer to a set of good values grounded on the bases of the Quranic verses and Prophetic traditions (Hamzah, 1978; Ali Kettani, 1984). As the revelations do not directly infer the values, studies refer to the elaboration made by contemporary scholars. 
Similar definition has been utilized by Abbas (1987), Monir (1997) as well as Forster and Fenwick (2014) in their studies.

This articles utilizes a set of Islamic values application based on the research of Ishak (2016). The research proposes 49 Islamic values practices resulting from a systematic process of psychometric properties development as suggested by (Spector, 1992). The proposed psychometric properties have resulted from Systematic Literature Review (Ishak \& Osman, 2016), followed by expert review and Fuzzy Delphi analysis (Ishak, Osman, \& Din, 2015). The psychometric properties were then evaluated via Rasch Model which confirms on its reliability (Ishak, Osman, Manan, \& Saidon, 2016; Ishak, Osman, Manan, et al., 2016; Ishak, 2016).

In the literature, empirical studies on human values have started since the 1970s, initiated by Rokeach (1973), through the validation of the Rokeach Value Survey (RVS). Since then, the RVS has grounded many studies (Hitlin \& Piliavin, 2004; Schwartz \& Bilsky, 1987). Nevertheless, the RVS has not considered any religious substance, particularly Islamic substance. However, it highlights on the ranking order of values, arranged according to their importance, which theoretically grounded the findings in this article.

The conception of Islamic values in this article is based on the ethical theory of al-Ghazali. The theory of Al-Ghazali has been widely referred as theoretical bases in studies of values (Latif, 2013; Ishak, 2016). Al-Ghazali's ethics suggests on the complementary function of man's reason to revelation (Muhammad, 1978; Mohd Khair, 2014). Thus, the list of values proposed are based on relevant revelations as single out by contemporary scholars (Ishak \& Osman, 2016). The psychometric properties are man's action which define the underlying values. This is in line with the theory of al-Ghazali which advocates that ethics is realized through actions (Muhammad, 1978).

\section{The Uniqueness of Islamic Value System}

In Islamic value system, iman (faith) and taqwa (piety) are the foundations which direct Muslims towards the right path in a rightful manner. Alhabshi and Ghazali (1994) further states that both faith and piety have influence on the behavior and character of an individual. Character is the state of soul which produces consistent and spontaneous physical actions. If the soul is pure, it will produce pure character consistently. In contrast, if the soul is impure, the character will be evil and bad. For instance, the value of brotherhood and unity will discourage a Muslim from inflicting harm towards others, and the value of responsibility

will encourage a person to perform his duties well. Furthermore, the belief in the oneness of God is capable of providing a strong abstaining and enforcing authority to observe ethical attitudes.

In Islam, ethics and values are akhlaq which uses the revelation as the standard to determine good from evil. On the other hand, the modern value system is based on previous inherited belief of the society and evolution of man and the surrounding and does not guarantee man are protected from bad deeds.

Islam as a way of life, distinguishes positive values from negative values. Good values are made obligatory will be rewarded, whereas bad values are prohibited and subject to punishment. The reward and punishment is the enforcer for the Muslims to apply the values. However, in western theory of value, human judgement establishes the standard of positive or negative values (Omar, 2010). For instance, the Rokeach theory of value was formed by man and tested on its validity and reliability through man as the respondents. Nevertheless, determination based on human judgement is not universal as every person have different interpretation (Yaakub, 1978).

Islamic value system is certain and fixed regardless of time, place and culture. This means what considered as bad today, will never be considered as good in the future. In contrast, modern value system determines positive or negative values based on society's acceptance. Thus the values are not universal, and may differ be- tween societies or change over time and space (Yaakub, 1978). Alhabshi (1994) further adds, as an example, modern society have been paving way towards liberalism and homosexual in the name of freedom and individual right. This reflects the changing of values due to changes in the society's belief over time. In secular societies, values are not affected by the religion, thus changes in values are possible and accepted.

In contrast, values underpin with religion is firm and sustainable. In Islamic value system, these elements remain prohibited as stated by Quranic injunctions (primary source in Islam) and will never be modified. For example, a simple act of lying is prohibited and will never be considered acceptable no matter what the rationale is. In addition, Hammoudeh (2012) further adds that in order to preserve the permanent values, self-control is important to ensure a person would not transgress.

Islamic value system enforces effectively through the system of Islamic legal rulings, which refers to wajib, sunat, harus, makruh dan haram (as explained in Table 1). Understanding this will ensure conformance of the values leading to a peaceful and harmony society. For example, the culture among the Malaysian Malays society to bend down the body while walking in front of the elders as a sign of respect is considered permissible, somehow encouraged, as it can create a harmonious culture and environment (Syed Ismail, 2010). Table 1 below explains effect of Islamic legal rulings on value system.

There are two important consequences following the above system of legal rulings. First, the system positions the feelings of hope (raja') and fear (khauf) towards The Creator. Hope that Allah will strengthen the faith and spirit to fulfill all His command and prohibition, and fear to transgress the commands and prohibition of Allah. Both lead to obedience. Second, the understanding of Islamic legal rulings will assist in realizing the values as a regulated code of ethics. This has been highlighted by al-Ghazali, quoting that values inculcated in human soul can produce good deeds spontaneously. Another scholar in akhlaq, Ibn Manzur, agreed by saying akhlaq is a reflection of values arising from man's inner self based on obedience towards the shariah (Syed Ismail, 2010).

Table 1: Explanation on Islamic Legal Rulings

\begin{tabular}{|l|l|l|}
\hline Hukum & Explanation & Effect on Islamic Value System \\
\hline Wajib & $\begin{array}{l}\text { Obligatory to } \\
\text { do, sinned if } \\
\text { left }\end{array}$ & $\begin{array}{l}\text { A person will perform the values with } \\
\text { faith and piety even it is not regulated in } \\
\text { the organization }\end{array}$ \\
\hline Sunat & $\begin{array}{l}\text { Encouraged to } \\
\text { do, not sinned } \\
\text { if left }\end{array}$ & $\begin{array}{l}\text { A person will perform for Allah's bless- } \\
\text { ings and rewards voluntarily eventhough } \\
\text { it is not regulated in the organisations }\end{array}$ \\
\hline Harus & $\begin{array}{l}\text { Permissible } \\
\text { either to d or } \\
\text { leave }\end{array}$ & $\begin{array}{l}\text { A person will be aware that the value is } \\
\text { permissible in Islam, thus the act will be } \\
\text { respected and not condemned }\end{array}$ \\
\hline Makruh & $\begin{array}{l}\text { Encouraged to } \\
\text { leave }\end{array}$ & $\begin{array}{l}\text { A person will be discouraged to perform } \\
\text { eventhough it is not a sin }\end{array}$ \\
\hline Haram & $\begin{array}{l}\text { Obligatory to } \\
\text { leave } \\
\text { Sinned if done }\end{array}$ & $\begin{array}{l}\text { A person will avoid and leave the deeds } \\
\text { based on faith and piety eventhough it is } \\
\text { not regulated }\end{array}$ \\
\hline
\end{tabular}

Furthermore, Islamic values permeate all spheres of human's life. Therefore, it symbolizes a holistic concept of positive values and its adaptability within the system of legal rulings in all facets of life. For instance, in quality management, Islamic values are believed capable of creating a conducive work environment (Khaliq, 1996; Kettani, 1988).

\section{Methodology}

The psychometric properties were presented in the form of questionnaire and administered to participants of ISO9001 training conducted by SIRIM, the Standards and Industrial Research Institute of Malaysia which is a statutory body of standard development and auditing authority. The respondents consist of management representatives, document controller or quality division staff who understands the ethical work environment in their organisa- 
tions. Out of 100 questionnaires distributed, 59 were returned with a response rate of $59 \%$.

For the specific purpose of this study, Rasch Model will be used due to its ability to propose a ranking order of importance via analysis of item difficulty. Rasch Model hails from IRT (Item Response Theory) which is a family of measurement models used to measure latent variables (DeVellis, 2003; Singh, 2004). It has been increasingly used especially in scale development studies (DeVellis, 2003). Though it has first been initiated in educational studies, IRT has been widely applied in testing and validating instruments in various branches of social sciences, such as Bechtel (1985), Albano (2009) as well as Salzberger and Koller (2013). Bechtel (1985) used Rasch for a consumer rating scale, Albano (2009) used Rasch for individual happiness scale and while Salzberger and Koller (2013) for their marketing scale.

As explained by Bond and Fox (2007), Rasch is probabilistic model which uses logit as measurement units, obtained by transforming ordinal data into interval data where the data can be mapped into a linear scale. Interval data is actually a requirement to perform factor analysis, but many existing studies are found to use ordinal data. Thus, factor analysis has been criticized for misconceptually equating ordinal scale with interval scale (Simblett \& Bateman, 2011; Hobart \& Cano, 2009; Muller \& Roddy, 2009). Nevertheless, Rasch solves it by transforming ordinal response into interval scale using probabilistic function (Linacre, 2002; Bond \& Fox, 2007; Azrilah et al. 2013).

Scholars including Azrilah et al. (2013), Tennant and Conaghan (2007), Bond and Fox (2007) as well as Singh (2004) have agreed that Rasch provides sufficient parameters for a good measurement with the ability of;

1. Providing a linear scale by transforming scores into probabilistic model using logit as measurement units.

2. Transforming ordinal data into interval data which enable further statistical analyses to be performed. Mathematical functions which are used to calculate various analyses require interval data in order to produce unbias and accurate results.

3. Providing suggestion for missing data by its probabilistic model. Rasch estimates a person's probable response to an item, by considering the person's ability and the item's difficulty.

4. Assessing items' quality by detecting misfit and outliers, which may be evaluated by three measures; the point measure correlation, the infit and outfit mean square (MNSQ) and the $\mathrm{z}$ standard.

5. Providing distinct measures for item difficulty and person ability, which may be arranged or ranked according to items difficulty or persons ability.

For the purpose of this study, logits values which reflect the persons'ability and iems difficulty will be used. The findings will be translated into the basic and advanced practices of values implementation in workplace. The following section reports on the ranking order of Islamic values as reflected by the logit values.

\section{Analysis and Discussion}

In specific, the proposal of basic and advanced list of values was achieved via Rasch Model profiling analysis on item difficulty. Profiling analysis means that the items are characterized according to their difficulty levels. Such analysis is attained based on logit values and may be illustrated in the person-item map. The map visualises ordered items' logit values. Besides the map, individual item logits are arranged orderly in the table of item measures in Winstep. Items below the item mean $(0.00)$ are considered as easy to endorse while items above the item mean $(0.00)$ are considered as difficult to endorse (Bond \& Fox, 2007). The hierarchical order provided by Rasch model is robust as it is able to function well even when there are missing data (Simko \& Linacre, 2010).

In the context of the current study, item difficulty ranges from easy to difficult to adopt practices of values, or the basic and advanced practices. Similar analysis has been utilised by Latif
(2013) to describe the behavioural levels of Malaysian students in the public higher learning institutes.

The hierarchical order of values is in line with the Rokeach theory of value which states that values have ranks of varying importance (Rokeach, 1973). In this study, an easily adopted practice reflects that the practice is very common among the organisations. These items are those with less than 0.00 logit, and are mapped below the mean item, in the person-item map. These items are proposed as basic practices of values. Thus, organisations may consider applying these practices in the first place. Table 2 lists the basic practices.

On the other hand, Rasch Model informs on difficult to endorse items indicated by logit values above item mean. In this study, a difficult to endorse item is less common among organisations. These items are items with logits larger than 0 , and are mapped above the item mean $(0.00)$, in the person-item map. These items are proposed as advanced practices of values. Hence, organisations may consider these practices to further improve and enhance their current application, or for future planning purposes. Table 3 lists the practices.

Table 2: List of basic practices of values

\begin{tabular}{|c|c|}
\hline Summary of items & Logit \\
\hline Permission to perform religious obligation & -2.37 \\
\hline Prayer room & -1.37 \\
\hline Meet terms of contracts & -1.29 \\
\hline Decisions consider public interest & -0.77 \\
\hline Correct based on audit comments & -0.64 \\
\hline Advertisement matches actual specifications & -0.56 \\
\hline Immediate response to complaints & -0.51 \\
\hline Customers' feedback & -0.47 \\
\hline Evaluate performance & -0.46 \\
\hline Official info channel & -0.44 \\
\hline Performance appraisal & -0.32 \\
\hline Transparent auditing & -0.31 \\
\hline Activities matched documentation & -0.26 \\
\hline Superior-subordinate relationship & -0.26 \\
\hline Activities follow plans & -0.24 \\
\hline Training of new knowledge & -0.23 \\
\hline Internal auditing & -0.21 \\
\hline Prepares audit together & -0.21 \\
\hline Allow staff to propose ideas & -0.17 \\
\hline Treat each other well & -0.17 \\
\hline Records non-compliance & -0.10 \\
\hline Equal training & -0.10 \\
\hline Training consistency & -0.09 \\
\hline Review work process & -0.09 \\
\hline Implement follow-up plans & -0.07 \\
\hline Benchmark for best practice & -0.04 \\
\hline Adoption of improved ways & -0.03 \\
\hline
\end{tabular}

Table 3: The list of advanced practices of values

\begin{tabular}{|c|c|}
\hline Summary of item & Logit \\
\hline Open day & 1.89 \\
\hline Special promotion & 1.81 \\
\hline Prayer (doa) & 1.51 \\
\hline Meetings end on time & 0.81 \\
\hline Risk management plan & 0.68 \\
\hline Training needs analysis & 0.54 \\
\hline Review of strategic planning & 0.36 \\
\hline Meetings start on time & 0.34 \\
\hline Management review meetings & 0.31 \\
\hline Customer satisfaction survey & 0.30 \\
\hline Recognise Q awards & 0.29 \\
\hline Factual-based decision making & 0.26 \\
\hline Accomplish work on time & 0.25 \\
\hline Room for customer feedback & 0.22 \\
\hline Adoption of new ways & 0.19 \\
\hline Corrects non-compliance immediately & 0.14 \\
\hline Best worker awards & 0.10 \\
\hline Dresscode & 0.06 \\
\hline Cooperation across departments & 0.04 \\
\hline Analyse customers' feedback & 0.04 \\
\hline
\end{tabular}




\section{Conclusion}

The ranking order of human values importance is theoretically parallel with the Rokeach theory of value. In this study, the ranking is proposed via Rasch Model analysis, as it offers a linear measurement scale based on logit measures. The item logit can be arranged orderly to propose a rank of items from the most difficult to the easiest practices. Based on the hierarchical order of logits, this study proposed a set of basic practices of Islamic values (Table 2), which may provide insight for

organisations in their early planning to instil Islamic values among the staff. In addition, this study also proposed another set of advanced practices of Islamic values (Table 3 ), which may provide insight for organisations as the consequent step to further improve or strengthen their value practices.

\section{Acknowledgment}

The authors would like to thank the Institute of Research Management and Innovation (IRMI) of Universiti Teknologi MARA for funding the research (600-IRMI/DANA KCM 5/3/LESTARI (187/2017)). The project funding starts in October 2017 and is expected to end within a 12-month period.

\section{References}

[1] Abbas Ali. (1987). Scaling an Islamic Work Ethic. The Journal of Social Psychology,

[2] 128(5), 575-583.

[3] Abdullah, A. L., Hamzah, A., Juhari, R., \& Hamid, J. A. (2005). The Muslim

[4] Religiosity-Personality Inventory ( MRPI ): Towards Understanding Differences in the Islamic Religiosity among the Malaysian Youth. Pertanika, 13(2), 173-186.

[5] Abulhasan M. Sadeq, \& Khaliq Ahmad. (1996). Quality Management Islamic

[6] Perspectives. Kuala Lumpur: Leeds Publications.

[7] Al-Khalifa, K. N., \& Aspinwall, E. M. (2001). Using the competing values

[8] framework to investigate the culture of Qatar industries. Total Quality Management, 12(4), 417-428. https://doi.org/10.1080/09544120124219

[9] Alhabshi, S. O., \& Ghazali, A. (1994). Islamic Values and Management. Kuala

[10] Lumpur: Institut Kefahaman Islam Malaysia.

[11] Asma Jana-Masri, \& Priester, P. E. (2007). The Development and Validation of a

[12] Qur'an-Based Instrument to Assess Islamic Religiosity: The Religiosity of Islam Scale. Journal of Muslim Mental Health, 2, 177-188.

[13] Azmi, I. A. G., Syed Ismail, S. H., \& Basir, S. A. (2013). Kualiti Perkhidmatan

[14] Awam Menurut Perspektif Islam. Kuala Lumpur: Penerbit Universiti Malaya.

[15] Azrilah Abdul Aziz, Mohd Saidfudin Masodi, \& Azami Zaharim (2013). Asas Model Pengukuran Rasch Pembentukan Skala \& Struktur Pengukuran. Bangi: Penerbit UKM.

[16] Baird, K., Hu, K. J., \& Reeve, R. (2011). The relationships between organizational culture, total quality management practices and operational performance. International Journal of Operations \& Production Management, 31(7), 789-814.

[17] Basir, S. A., Che Pa, B., \& Raja Sulong, R. H. (2010). Suntikan nilai-nilai Islam ke atas perlaksanaan penambahbaikan berterusan dalam konteks Sistem Pengurusan Kualiti ISO9000. Jurnal Syariah, 18(1), 91-122.

[18] Bond, T. G., \& Fox, C. M. (2007). Applying the Rasch Model Fundamental Measurement in the Human Sciences (2nd ed.). New York: Routledge Taylor \& Francis Group.

[19] Denison, D. R., \& Spritzer, G. M. (1991). Organizational culture and organizational development. Research in Organizational Change and Development, 5, 1-21.

[20] Forster, G., \& Fenwick, J. (2014). The influence of Islamic values on management practice in Morocco. European Management Journal.
[21] Gambi, L. D. N., Gerolamo, M. C., \& Carpinetti, L. C. R. (2013). A Theoretical Model of the Relationship between Organizational Culture and Quality Management Techniques. Procedia - Social and Behavioral Sciences, 81, 334-339.

[22] Hammoudeh, M. M. (2012). Islamic Values and Management Practices. England: Gower Publishing Limited.

[23] Hitlin, S., \& Piliavin, J. A. (2004). Values: Reviving a Dorman Concept. Annual Review of Sociology, 30(1), 359-393.

[24] Hitti, P. K. (1960). History of the Arabs. London: McMillan \& Co Ltd.

[25] Ishak, A. H. (2016). Developing a Scale to Assess Islamic Values Application in Quality Management: A Study Among Malaysian Organisations. Universiti Teknologi MARA.

[26] Ishak, A. H., \& Osman, M. R. (2015). Conceptualising the Influence of the

[27] Islamic Value System on Quality Management Effectiveness. In R. Hashim \& A. B. A. Majeed (Eds.), Proceedings of the Colloqium on Administrative Science and Technology. Springer.

[28] Ishak, A. H., \& Osman, M. R. (2016). A Systematic Literature Review on Islamic

[29] Values Applied in Quality Management Context. Journal of Business Ethics, 138(1), 103-112. https://doi.org/10.1007/s10551-0152619-z

[30] Ishak, A. H., Osman, M. R., \& Din, G. (2013). Conceptualizing Organizational

[31] Effectiveness in Light of Islamic Value System. International Journal of Social Science and Humanity, 3(6), 532-537.

[32] Ishak, A. H., Osman, M. R., \& Din, G. (2015). Expert consensus on dimensions

[33] of Islamic values in quality management practice: Analysis of Fuzzy Delphi method. Turkish Online Journal of Educational Technology, 2015, 273-279.

[34] Ishak, A. H., Osman, M. R., Manan, S. K. A., \& Saidon, R. (2016). Rasch model

[35] scale calibration analysis for Islamic value. International Review of Management \& Marketing, 6(7), 11-16.

[36] Ishikawa, K. (1985). What is Total Quality Control? The Japanese Way. London:

[37] Prentice Hall.

[38] Kettani, A. (1984). Science and technology in Islam: The underlying value

[39] system. In Ziauddin Sardar (Ed.), The Touch of Midas: Science, Values and Environment in Islam and the West. Manchester: Manchester University Press.

[40] Khaliq Ahmad. (1996). Quality management foundation: an agenda for

[41] Islamization of management knowledge. Malaysian Management Review, 31(1), 44-52.

[42] Lagrosen, S. (2003). Exploring the impact of culture on quality management.

[43] International Journal of Quality \& Reliability Management, 20(4), 473-487.

[44] Latif, A. A. (2013). Pembangunan Instrumen Penilaian Akhlak Pelajar di Institut

[45] Pengajian Tinggi Awam. Universiti Teknologi Malaysia.

[46] Maull, R., Brown, P., \& Cliffe, R. (2001). Organisational culture and quality

[47] improvement. International Journal of Operations \& Production Management, 21(3), 302-326.

[48] Mohd Khair Eiadat. (2014). Community of One : Al-Ghazali’s Ethical Theory

[49] Revisited. Human and Social Sciences, 41(1), 302-314.

[50] Monir Tayeb. (1997). Islamic revival in Asia and human resource management.

[51] Employee Relations, 19(4), 352-364.

[52] Muhammad A. Al-Buraey. (2005). Management Principles Derived from the

[53] Sources of Islam. In Mazilan Musa \& S. S. S. M. Salleh (Eds.) Quality Standard from the Islamic Perspectives. Kuala Lumpur: IKIM.

[54] Muhammad Abul Quasem. (1978). The Ethics of al-Ghazali: A Composite Ethics in

[55] Islam. New York: Caravan Books.mar, M. N. (2010). Falsafah Akhlaq. Bangi: Penerbit UKM.

[56] Philips, A. A. B. (1995). The Evolution of Fiqh. Riyadh: International Islamic Publishing House.

[57] Prajogo, D. I., \& McDermott, C. M. (2005). The relationship between total quality management practices and organizational cul- 
ture. International Journal of Operations \& Production Management, 25(11), 1101-1122.

[58] Prajogo, D. I., \& McDermott, C. M. (2011). The relationship between multidimensional organizational culture and performance. International Journal of Operations \& Production Management, 31(7), 712-735.

[59] Rokeach, M. (1973). The Nature of Human Values. Free Press.

[60] Sany Sanuri Mohd Mokhtar, Rushami Zien Yusoff, Zakaria Abas, Hartini Ahmad, Muhammad Nasri Md Hussain, \& Wazin Man@Othman. (2011). Aplikasi Sistem Pengurusan Kualiti dari Perspektif Islam. Sintok: Penerbit UUM.

[61] Sarion, A., Bustamam, U. S. A., \& Shaharudin, A. (2014). Towards MS1900 : 2014 quality management system from Islamic perspective: A case study at MACS. International Journal of Islamic and Civilizational Studies, 1(1), 8-17.

[62] Schwartz, S. H., \& Bilsky, W. (1987). Toward a universal psychological structure of human values. Journal of Personality and Social Psychology, 53(3), 550-562.

[63] Simko, I., \& Linacre, J. M. (2010). Combining partially ranked data in plant breeding and biology: I. rank aggregating methods. Communications in Biometry and Crop Science, 5(1), 56-65.

[64] Singh, J. (2004). Tackling measurement problems with Item Response Theory. Journal of Business Research, 57(2), 184-208.

[65] Spector, P. E. (1992). Summated Rating Scale Construction: An Introduction. California: Sage Publications.

[66] Tennant, A., \& Conaghan, P. G. (2007). The Rasch measurement model in rheumatology: What is it and why use it? When should it be applied, and what should one look for in a Rasch paper? Arthritis Care and Research, 57(8), 1358-1362.

[67] Yaakub, H. (1978). Etika Islam Pokok-pokok Kuliah Ilmu Akhlaq. Jakarta: CV Publicita.

[68] Zu, X., Robbins, T. L., \& Fredendall, L. D. (2010). Mapping the critical links between organizational culture and TQM/Six Sigma practices. International Journal of Production Economics, 123(1), 86-106. 